\title{
ネコ肺動脈における自律神経支配
}

—とくに non adrenergic non cholinergic inhibitory system

の 存 在について 一

佐賀医科大学 小児科学教室

浜崎雄平

Department of Medicine, University of Oklahoma

Sami I. SAID

\section{AUTONOMIC NERVE INNERVATION OF CAT PULMONARY ARTERY}

\author{
Yuhei HAMASAKI
}

Department of Pediatrics, Saga Medical School, Saga

Sami I. SAID

Department of Medicine, University of Oklahoma Health Science Center

Electrical field stimulation (EFS), transmural nerve stimulation, was utilized to investigate autonomic nerve innervation of cat pulmonary artery. EFS (duration; 0.8 msec or $1.0 \mathrm{msec}$, frequency; $20 \mathrm{~Hz}$, voltage; $70 \mathrm{~V}$, for $15 \mathrm{sec}$ ) induced small fast constriction followed by large prolonged relaxation on prostaglandin $\mathrm{H}_{2}$ analogprecontracted cat pulmonary arterial strip which was suspended in a $10 \mathrm{~m} l$ organ bath. The small fast constriction was blocked or considerably reduced by addition of phenoxybenzamine. The relaxation was partially blocked in some strips by addition of atropine and/or propranolol. Teterodotoxin or lidocaine not only blocked relaxation which was not blocked by atropine or propranolol, but also farther reduced or completely blocked the relaxation which was partially blocked by atropine and/or propranolol. It is concluded that (1) $\alpha$-adrenergic nerve regulates pulmonary arterial constriction, (2) $\beta$-adrenergic and cholinergic regulations may be present, but their roles may be substantially small and (3) non adrenergic non cholinergic nerve may play major roles in inhibitory regulation of cat pulmonary circulation.

\section{I. 緒}

肺循環系において興奮系 (excitatory)，抑制 系 (inhibitory) 両系の自津神経がいかなる調節 的役割をはたしているかは、いまだ明確でない。 交感神経線維は主肺動脈, 主肺静脈, 及び小 抵抗血管に分布していることが解剖学的に認め られて拈り (Bergofsky, 1979) $\alpha-, \beta$-交感神経
言

レセプターも肺動脈平滑筋に豊富に分布してい ることが良く知られている (Bergofsky, 1979). これらの事実より， $\alpha$-交感神経系が excitatory に, $\beta$-交感神経が inhibitoryに何らかの調節作 用を扮こなっていることは十分に予想される。 一方副交感神経の役割はあまりあきらかではな 
い. 副交感神経伝達物質である acetylcholine は肺循環系に対して excitatoryに動く場合 (Aviado, 1965), inhibitory 飞働く場合の両方 が報告されているが (Rudolph, 1958)，トーヌ スを上昇した状態に扮いては inhibitoryに働 くことが知られている (Rudolph, 1958; Hamasaki, 1983). Daley (1957) は神経刺激に より,肺動脈にひさ括こされた肺血管抗張を, 副 交感神経由来の線維刺激によるものと報告して いるし, 副交感神経起原の神経線維が肺血管に 分枝を送っていることは認められているものの (Harris，1977)，肺血管筋層そのものへの分布 は明確でなく，副交感神経そのものが何らかの 調節的役割をしているかだらかも現在のところ 明らかではない。

ところで, 近年, 種々の哺乳動物の気道, 消 化管, 血管等種々の臓器に㧤いて, 交感神経 (adrenergic) でも副交感神経 (cholinergic) で もない，第 3 の抑制系 (inhibitory) 自津神経 (non adrenergic, non cholinergic nerve) の存 在が証明されてきて抢り, 臓器によっては最も 主要な inhibitoryの調節作用をつかさどって いることが認められてきている (Cobern, 1973 ; Irvin, 1979 ; Bülbring, 1966 ; Hughes, 1967 ;
Bloom, 1980). この non adrenergic non cholinergic nerve の神経伝達物質は今のところ不 明である。また単一の伝達物質をもつ神経系で あるのか, 複数の伝達物質により作動する種々 の神経の集合であるのかも明確でないが，非常 に広範に分布していることが次第に明らかに なっている. Hand ら (1983) は最近モルモット の肺動脈にも non adrenergic inhibitory nerve の存在を報告している。この第 3 の自律神経系 を含めて, 肺循環に拈ける自律神経調節の機構 及び意義（特に inhibitory nerve）についてはほ とんどといってよいほどわかっていない。

ところで, 1955 年に Paton らは平滑筋の摘出 切片を organ bath 中で灌流し, bath 中に設置 した電極で，きわめて短い幅の連続矩形波を用 いて刺激することにより (Electrical Field Stimulation, transmural nerve stimulation, EFS）ある条件下では平滑筋を直接刺激するこ となく，神経刺激を介した筋肉の反応をひき抏 こすことを見いだした。

我々はこの EFS テクニックスを用いて，ネ コ肺動脈に和ける自律神経の調節機序(特に, 肺 動脈の拡張をひき抏こす inhibitory nerve system を検討した。

\section{II. 実験材料 及び 方法}

実験には28 匹の雑種ネコ(雌雄, $1.3-4.2 \mathrm{~kg}$ ) を使用した。実験動物はペントバルビタールナ トリウム $100 \mathrm{mg} / \mathrm{kg}$ 静注にて麻酔し開胸した。 主肺動脈から左右の肺動脈分岐部までを摘出 し，結合織をとりのぞいたあと，水冷 Krebs Ringer 液（組成 $\mathrm{mM} / l: \mathrm{NaCl} ; 117.6, \mathrm{KCl}$; $5.4, \mathrm{MgSO}_{4} ; 1.2, \mathrm{NaHCO}_{3} ; 25.5, \mathrm{NaH}_{2} \mathrm{PO}_{4}$; 1.0, glucose ; $\left.11,1, \mathrm{CaCl}_{2} ; 2.5\right)$ にて洗浄した. 肺動脈はらせん状に切り, $20 \mathrm{~mm} \times 2 \mathrm{~mm} の$ 平滑筋切片とした。肺動脈切片は $95 \% \mathrm{O}_{2}+5 \%$ $\mathrm{CO}_{2}$ の混合気で酸素化した Krebs 液をみたした 容積 $10 \mathrm{~m} l$ の organ bathの中につり下げた. Organ bath には $37^{\circ} \mathrm{C} に$ 温めた新鮮な Krebs 液を reservoirより循環ポンプ (Harvard model 2671) をもちいて $4 \mathrm{ml} / \mathrm{min} て ゙$ 連続的に 供給した. 肺動脈切片は, この方法により 10 時
間以上にわたって安定した反応を示した。肺動 脈切片上端は, 張力トランスデューサー (isometric; Harvard 363) 飞連結し, 張力の変化 をレコーダー(Beckman) に紙括くり速度 5 $\mathrm{mm} / \mathrm{min}$ で連続的に記録した。約 20 分後, 筋 トーヌスが安定したのち, 筋の弛緩を検出しや すくする目的で, 合成プロスタグランディン $\mathrm{H}_{2}$ 誘導体 ((15s)-hydroxy-11 $\alpha, 9 \alpha$-(epoxymethano) prosta $5 z, 13 \mathrm{e}$-dienoic acid) を最終 濃度 $0.05 \mu \mathrm{g} / \mathrm{m} l$ となるように Krebs 液 reservoir に加光ることにより, 肺動脈切片の平滑筋 トーヌスを上昇させた。実験に使用した 0.05 $\mu \mathrm{g} / \mathrm{m} l$ の $\mathrm{PGH}_{2}$ analog $\mathrm{Krebs}$ 液中できわ めて安定で, 肺動脈切片に submaximal の収縮 をひきおこし, $\mathrm{PGH}_{2}$ analog の灌流を続けるか ぎり，そのトーヌスを維持することができた。 


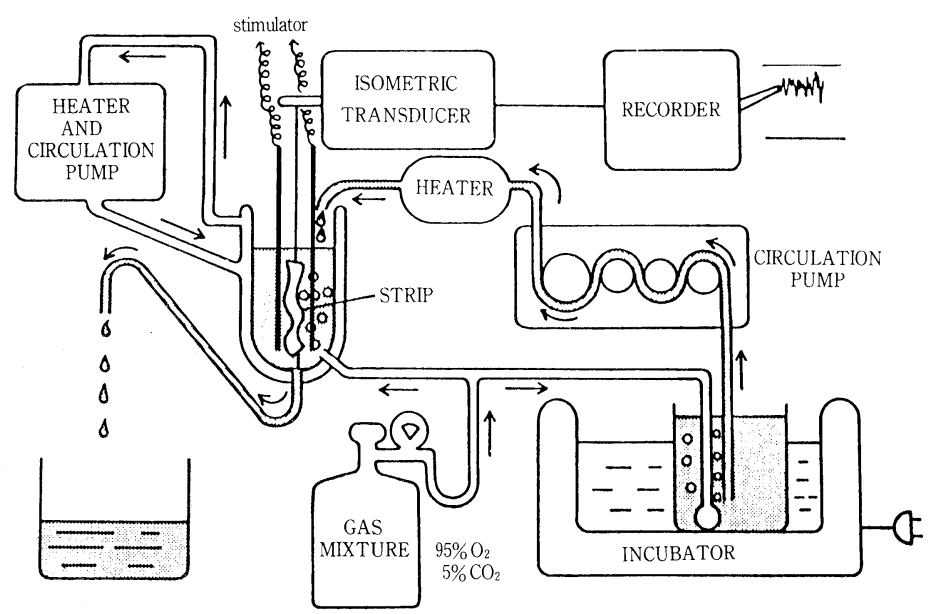

図 1. 実験装置の概略：肺動脈切片の下端 $(20 \mathrm{~mm} \times 2 \mathrm{~mm})$ を, 酸素化した Krebs-Ringer 液をみたした organ bath 底に固定し，切片の上端は張力トランスデューサーに固定した，EFSの目的で， 2 本の平 行な白金電極を平滑筋切片に平行に留置した。張力の变化を，レコーダーを介して記録用紙上に 5 $\mathrm{mm} / \mathrm{min}$ の紙拈くり速度で記録した。

EFS の目的で organ bath 中に, 2 本の白金電 極を，つり下げられた肺動脈切片に平行に，か つ切片に直接接触しないように $10 \mathrm{~mm}$ の間隔 で設置した。電極の他端は, Grass model S-48 electric stimulator に連結した。装置の概略を 図 1 に示す。 EFS は $20 \mathrm{~Hz}, 70 \mathrm{~V}$ の連続矩結形 波で 15 秒間扢こない，刺激波の幅は通常，神経 刺激のみをひき扮こすとされる $0.8 \mathrm{msec} と 1.0$ msecを使用した。 Phenoxybenzamine, propranolol, atropine, lidocaine (これらの blockers はすべて市販の標品を使用した）はすべて Krebs 液 reservoir 中に加えることにより目的 とする濃度を得た。 Blockerのうち tetrodotoxin のみは $10 \mathrm{~m} l$ organ bath 中に直接加えた。 organ bath中に加えられた薬物は, 装置の性状 より，連続的に希釈されるわけであるが，便宣 上, 最初に加えた時の organ bath 中の濃度を計
算によりもとめ示した. EFS によりひき扤こさ れる弛緩（扔よび収縮）の各 blockerによる抑 制（抢よび増強）は以下の計算式によりもとめ た。

$\%$ 抑制 (増強) =

\section{各 blocker 投与前の弛緩(收縮) - 各 blocker 投与後の驰緩(收縮 各 blocker 投与前の弛緩(収縮)}

Blockers の投与はまず phenoxybezamine, 次 に atropine, 更に propranolol 最後に lidocaine or tetrodotoxin の順とした。 ただし，ある実験 では, propranolol と atropine の順序をいれか 光た。これらの blockersは tetrodotoxin をの ぞいてすべて Krebs 液 reservoir 中に次々と投 与したので，一旦投与したのちは，特に言及し ない場合，同量が実験を通じて Krebs 液中に 入っていることになる.

\section{III. 実 験 成 績}

あらかじめ $\mathrm{PGH}_{2}$ analog でトーヌスを上昇 させた肺動脈切片は, EFS (1.0 msec, $20 \mathrm{~Hz}$, $70 \mathrm{~V})$ で速い，かつ小さい収縮を示したのち，長 い大きい弛緩を抗こした(図 2A)，1 msec EFS による速い収縮は $2 \mu \mathrm{g} / \mathrm{m} l$ の phenoxybenzamine そより全例 (13 切片中 13)抑制をらけ，そ
の程度は $67.4 \pm 7.6 \%$ であった(図 $2 \mathrm{~B}$, 表 1). 逆 に，収縮後の弛緩は, $66.8 \pm 23.2 \%$ の増強を見た (13切片中 7). $1 \mu \mathrm{g} / \mathrm{m} l$ の atropine (cholinergic blocker)を, Krebs 液 reservoir へ加光 たのち (acetylcholine の作用を完全に block す る), 1 msec EFS で刺激すると, 弛緩は 7 切片 


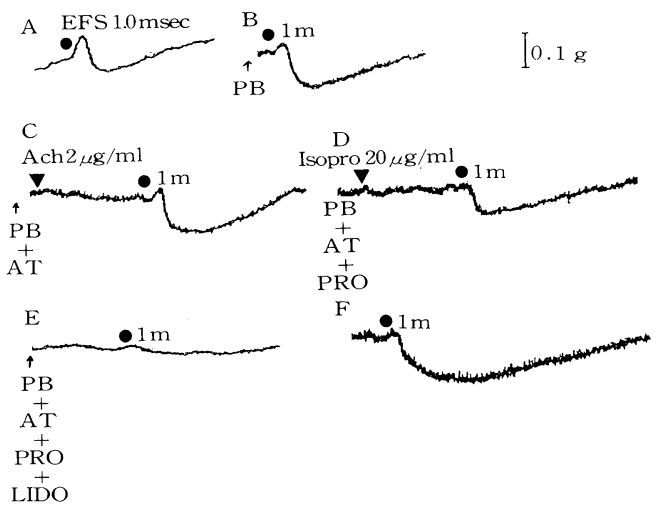

図 2. (A) $\mathrm{EFS}(\boldsymbol{O}$; msec, $2 \mathrm{~Hz}, 70 \mathrm{~V}$ for $15 \mathrm{sec})$ は，小さな速い収縮をひきおこし，ひきつづ き長い弛緩をひき⿰扌こした。

(B) phenoxybenzamine (PB; $2 \mu \mathrm{g} / \mathrm{m} l$ ) は，小さい速い収縮を抑制し，ひきつづき拉 こる弛緩を増強した。

(C) Atropine (AT; $1 \mu \mathrm{g} / \mathrm{ml}$, これは acetylcholine の作用をblockするに十分な濃 度) は，この平滑筋切片に执いては弛緩を抑 制しなかった。

(D) (Pro; $2 \mu \mathrm{g} / \mathrm{m} l$, isoproterenol の作用 をblockするに十分な濃度) は，一部弛緩を 抑制した。

(E) Lidocaine (Lido；20 $\mu \mathrm{g} / \mathrm{m} l$ ) は，ほぼ 完全に弛緩を抑制した。

(F) Reservoir 中 Krebs 液を blockersを含 まないKrebs 液に変光たのち，十分に平滑筋 片を洗浄し, $1 \mathrm{msec}$ の幅の EFS で刺激した ところ，弛緩は再びひき抗こされた。

中 4 切片で抑制され，その程度は $24.9 \pm 10 \%$ で あった（図 $2 \mathrm{c}$ ，表 2 ). 更に, $2 \mu \mathrm{g} / \mathrm{m} l$ の propranolol ( $\beta$-blocker) を Krebs 液 reservoir へ 加光たのち（この濃度は isoproterenol の作用 をblock した), 1 msec EFS で刺激すると, 弛 緩は 7 切片のらち 3 切片で抑制され, その程度 は $21.2 \pm 10.0 \%$ であった(図 $2 \mathrm{D}$, 表 2 )。この実 験で示された如く, atropine, propranolol はあ る切片に沶いて，弛緩を20-25\% 抑制するが， inhibitory nerve system に扔いて中心的役割 ははたしていない.次に $20 \mu \mathrm{g} / \mathrm{m} l$ の lidocaine (local anesthesia) Krebs 液 reservoir に投 与して神経 blockを試みた。 Lidocaine は propranolol もしくは atropine により抑制を受け なかった切片の弛緩を抑制もしくは完全に blockしたのみならず propranolol, atropine により部分的に抑制された弛緩も更に抑制もし
表 1. Inhibition of small fast contraction and enhancement of large prolonged relaxation induced by EFS after addition of phenoxybezamine $(2 \mu \mathrm{g} / \mathrm{m} l)$

\begin{tabular}{c|c|c}
\hline \multirow{2}{*}{$\begin{array}{c}\text { Inhibition of contraction } \\
\text { frequencies } \\
\text { \% inhibition }\end{array}$} & 0.8 & 1.0 \\
\cline { 2 - 3 } $\begin{array}{c}\text { Enhancement of relaxation } \\
\text { frequencies } \\
\% \text { enhancement }\end{array}$ & $65.7 \pm 9.7$ & $13 / 13$ \\
& $8 / 13$ & $7 / 13$ \\
\hline
\end{tabular}

くは完全に blockした（6例中 6 例, $74.4 \pm 6.4$ $\%$ )(図 2E, 表 2). これら一連の実験ののち, こ の切片では reservoir 中の Krebs 液をいずれの blockersをも含まない新しいKrebs 液にかえ $\left(\mathrm{PGH}_{2}\right.$ analog は同量含む) 1 時間以上灌流し， blockersをあらいながしたのち，同じ $1 \mathrm{msec}$ EFS で刺激した. 再びほぼ同程度の弛緩がひき 物こされた。しかしながら，早い収縮は 1 時間 新しい， blockerを含なないKrebs 液で洗った にもかかわらず出現しなかった（図 $2 \mathrm{~F}$ ). Phenoxybenzamine の作用はきわめて長くつづき, 新しいKrebs 液で 1 時間洗うことによって消 失しないことがわかった。

同じプロトコールの実験を $0.8 \mathrm{msec}$ 幅の EFS で拈こない（図 3) 同様の結果を得た。各 blockerによる抑制 (増強)の頻度と程度は表 1 と表 2 にまめて示した。 この切片では, 図 $3 \mathrm{E}$ に示す如く, $4 \mu \mathrm{g} / \mathrm{m} l$ tetrodotoxin でも神経 blockを試みた。 Tetrodotoxin は lidocaine と 同じく propranolol， atropine 抵抗性の弛緩を $70 \%$ 以上抑制した。

ところで，本実験では transmural な神経刺 激を得る目的で $0.8 \mathrm{msec}, 1.0 \mathrm{msec}$ 幅の連続矩 形波 $(20 \mathrm{~Hz}, 70 \mathrm{~V}, 15$ 秒間) を使用したが，刺 激波の幅を広くしていくと，神経刺激のみなら ず，筋肉の直接刺激をもひき扣こすことが文献 上知られている。したがって，どのくらいの幅 の刺激がネコ肺動脈に筋肉刺激をひさ怙こすか についても検討を加えた。図 4 に示す如く, 肺 動脈切片を $10 \mu \mathrm{g} / \mathrm{m} l$ lidocaine 存在下に種々 の (0.8-8.0 msec) 幅の連続矩形波で刺激してや 
A
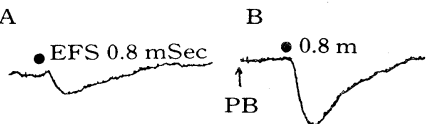

D

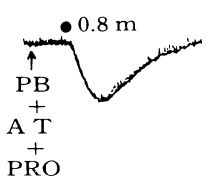

E

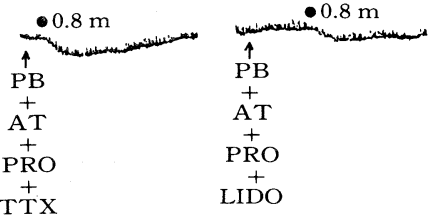

図 3. (A) $\mathrm{EFS}$; $0.8 \mathrm{msec}, 20 \mathrm{~Hz} 70 \mathrm{~V}$ for 15 sec)は，図 2 と同様に小さな速い収縮をひき 招こし，ひきつづき長い弛緩をひきおこし た.

(B) Phenoxybenzamine (PB; $2 \mu \mathrm{g} / \mathrm{m} l$ ) は 初期の速い収縮を完全に抑制した。

(C) Atropine (AT; $1 \mu \mathrm{g} / \mathrm{m} l$ は、弛緩を抑 制できなかった。

(D) Propranolol (Pro ; $2 \mu \mathrm{g} / \mathrm{m} l$ ) 驰緩を 抑制できなかった。

(E) Tetrodotoxin (TTX ; $4 \mu \mathrm{g} / \mathrm{m} l$ ) は，明 らかに弛緩を抑制した。

(F) Lidocaine (Lido; $20 \mu \mathrm{g} / \mathrm{ml}$ ) は tetrodotoxin で抑制された弛緩を更に抑制した。

表 2. Inhibition of prolonged relaxation induced by EFS after additions of propranolol, atropine, tetrodotoxin and lidocaine

\begin{tabular}{cl|c|c} 
& & \multicolumn{2}{|c}{ duration of pulse $(\mathrm{msec})$} \\
\cline { 3 - 4 } & & 0.8 & 1.0 \\
\hline propranolol & frequencies & $2 / 5$ & $3 / 7$ \\
$(2 \mu \mathrm{g} / \mathrm{m} l)$ & $\%$ inhibition & $6.0 \pm 4.5$ & $21.2 \pm 10.0$ \\
atropine & frequencies & $4 / 6$ & $4 / 7$ \\
$(1 \mu \mathrm{g} / \mathrm{m} l)$ & $\%$ inhibition & $40.0 \pm 13.4$ & $24.9 \pm 10.0$ \\
tetrodotoxin & frequencies & $1 / 1$ & $1 / 1$ \\
$(4 \mu \mathrm{g} / \mathrm{m} l)$ & $\%$ inhibition & 70 & 76.9 \\
lidocaine & frequencies & $5 / 5$ & $6 / 6$ \\
$(20 \mu \mathrm{g} / \mathrm{m} l)$ & $\%$ inhibition & $79.1 \pm 7.9$ & $74.4 \pm 6.4$ \\
\hline
\end{tabular}

ると, $0.8 \mathrm{msec}, 1 \mathrm{msec}$ 幅の EFS による弛緩 は, lidocaine で注汸完全に block されたが, 1.5 msec 幅の EFS による弛緩は完全には抑制で きず，幅を増すにつれて lidocaine により抑制 されない弛緩の割合が増加していくことがわ かった。この結果より $1 \mathrm{msec}$ 以下の幅の連続 矩形波は主に神経刺激を介して筋肉の反応をお こすといらことが示された。

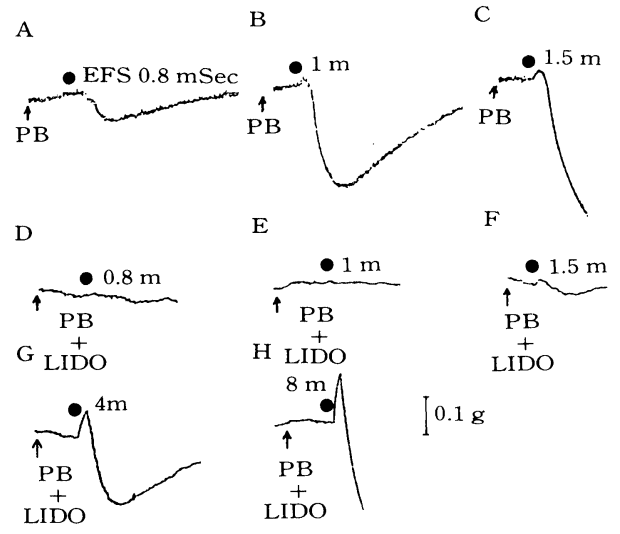

図 4. (A), (B), (C) 3 つのことなった幅の EFS (A；0 $8 \mathrm{msec}$, B ; $1.0 \mathrm{msec}$, C ; $1.5 \mathrm{msec}, 20 \mathrm{~Hz}$, $70 \mathrm{~V}$, for $15 \mathrm{sec}$ ) は, ネコ肺動脈平滑筋片に 弛緩をひき括こした。(D)，(E)，(F) Lidocaine $10 \mu \mathrm{g} / \mathrm{m} l$ を reservoir 中に投与したのち, 同様の刺激を与兄ると, $0.8 \mathrm{msec}, 1.0 \mathrm{msec}$ で潘㜔宔に, $1.5 \mathrm{msec}$ 幅の EFS において も，90\% 以上の抑制がみられた。(G)，(H) 4.0 msec, $8.0 \mathrm{msec}$ 幅の EFS で刺激すると, 弛 緩は完全には抑制されず，筋の直接刺激が出 現してきた。
A
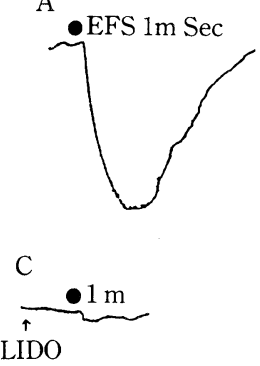

B Ach200 $\mathrm{ng} / \mathrm{ml}$

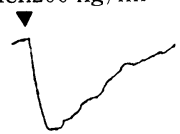

D Ach $200 \mathrm{ng} / \mathrm{ml}$

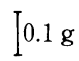

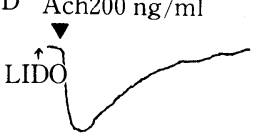

図 5. (A) $\mathrm{EFS}(1 \mathrm{msec}, 20 \mathrm{~Hz}, 70 \mathrm{~V}$ for 15 sec)は平滑筋切片に, 大きい長くつづく驰緩 をひき抗こした。

(B) $200 \mathrm{ng} / \mathrm{m} l$ の acetylcholine \&, 同様に 弛緩をひき抗こした。

(C) Lidocaine $20 \mu \mathrm{g} / \mathrm{m} l$ 投与後, EFS によ る他緩は抑制されたが，(D) Acetylcholine による驰緩は抑制されなかった。

局麻剂 lidocaine の作用は, 末梢神経の block であり，筋に対する作用はないか，もしくはあっ ても弱いと考学られているが，本当に本実験で 使用した濃度の lidocaine が平滑筋に対し直接 抑制作用がないかどらか子検討した。図 5 に示 寸如く, $20 \mu \mathrm{g} / \mathrm{m} l$ の lidocaine は $1 \mathrm{msec}$ 幅の 
EFS による弛緩をほぼ完全に抑制したが，200 $\mathrm{ng} / \mathrm{m} l$ の acetylcholine は lidocaine 投与にか かわりなく同等の弛緩をひき抗こし，この濃度

\section{IV. 考}

Paton (1955) により確立された Electric Field Stimulationの方法は, 神経線維そのもの を摘出することなしに平滑筋中の神経を transmural に刺激できることより，平滑筋の摘出切 片を用いて容易に自律神経系の支配・役割をし らべることを可能にした。その際問題となるの は，いかなるパラメーターの矩形波を使用する ことにより純粋に，筋に対する直接刺激なしに 神経刺激を引き出すことができるかということ である。最も問題になるのは，矩形波の幅であ る.ネコの肺動脈切片を用いた本実験で, $10 \mu \mathrm{g} /$ $\mathrm{m} l$ の lidocaine は $0.8 \mathrm{msec}$ 及び $1.0 \mathrm{msec}$ の幅 の EFS による弛緩をほぼ完全に抑制したが, 1. $5 \mathrm{msec}$ 以上の幅の EFS による弛緩は完全には 抑制できず，更に幅が広がるにつれ抑制の度合 は低下した。このことは $1.5 \mathrm{msec}$ 以上の幅の刺 激では，神経刺激に加光て筋刺激をひき挆こす 可能性があることを示している. Coburnら （1973）は，モルモットの気道平滑筋を使用した 同様の実験で, 刺激の幅が $0.5 \mathrm{msec}$ 以上になる とすでに筋肉刺激が出現し，幅をますごとに筋 肉刺激の割合が上昇することを報告している。 ヒトの気道平滑筋を使用した Richardsonら (1976)は, tetrodotoxin が $2.0 \mathrm{msec}$ 幅までの刺 激をblock したことを報告して抢り，種による 差, 器官による差, organ bath 等の実験条件に よる影響も考えられる。彼らはをた blockers が，神経に到達するために結合織を十分にとり のぞくことが必要であることも指摘している (Richardson, 1976).

ところで, EFS による神経刺激は, 肺動脈切 片にきわめて速い小さな収縮と，ひきつづきお こる長い弛緩をひき挆こす。本実験では肺動脈 切片は, $\mathrm{PGH}_{2}$ analogにより submaximal の 状態にあらかじめ基本的トーヌスをあげている ので，収縮がはっきりとは示されない場合が多 いが，この小さい速い収縮は $\alpha$-blocker pheno-
では, lidocaine の筋への直接抑制作用は無視し てよいことが示された。

\section{察}

xybenzamine，により抑制されることにより， $\alpha$-adrenergic 由来であることがわかる。また, ひさつづき拈こる弛緩が phenoxybenzamine により増強することも $\alpha$-stimulationによる 収縮刺激が抑制されたためと考兄られ，そのこ とをららつけている。いずれにしても, excitatory nerve, $\alpha$-adrenergic nerve が肺動脈内に 存在し，何らかの tonic な調節をおこなってい る可能性を示している。市たこれは解剖学的な 結果と一致している (Bergofsky, 1979).

次に，本実験の主な目的である inhibitory system に関してのべる.肺循環系は低抵抗系血 管であり，生理的な状態に执いては肺血管の トーヌスはほとんどないにひとしい。したがっ て拡張を支配する自律神経系の役割をしらべる にはトーヌスを上げてやる必要がある (Rudolph, 1958)。本実験に括ける如く, 基本的 トーヌスを上昇してやると，あきらかに神経刺 激による長い大さい拡張が出現してくる，Propranolol ( $\beta$-blocker), atropine (cholinergic blocker) により，弛緩は 6-40\% 抑制されるこ とが，ある切片では認められた。しかしいずれ にしても atropine, propranololによる抑制は 軽度であり，個体差も大きく， $\beta$-adrenergic nerve, cholinergic nerve systems tory nerve systemにおいて主な役割をはたし ていないと思われる。ところで, propranolol, atropine により抑制されなかった弛緩も，軽度 に抑制された弛緩も，神経 blockerである tetrodotoxin, lidocaine に上り全例 70\% 以上 抑制された。このことはネコ肺動脈に拈けるこ の長い大きい矽緩が主に non adrenergic, non cholinergic な神経刺激によるものであること を示している。種々の臓器におけるnon adrenergic, non cholinergic nerve の伝達物質は 現在のところ不明である。ATP，ある種の neuropeptides (vasoactive intestinal peptide, 
Enkephalin, substance-P)等がその候補として あげられているが (Bloom, 1980; Matsuzaki, 1980 ; Lundberg, 1979 ; Burnstock, 1975) adrenergic nerve, chlinergic nerve に対しての 如き特異的 blockers が発見されていないこと もあり，薬理学的に証明することは今のところ 困難な状況である。

次に，肺循環系に括ける inhibitory system の生理学的, 病理学的意義であるが, 前述の如 く生理的な状況に抢いては肺血管のトーヌスは ほとんどないことが知られて括り，この inhibi-

\section{V. 結}

1. EFS テクニックを利用して。ネコ肺動脈 自律神経（特に inhibitory nerve system の支 配, 作用について検討した。

2. $\alpha$-交感神経は，ネコの肺動脈を収縮させ ることょり肺循環の調節に寄与している可能性 が示された。

3. $\beta$-交感神経, choline 作動性 inhibitory tory nerve system が通常の状態で, moment to moment の調節を抏こなっている可能性は少 なく, もっと chronic にトーヌスを決定・維持す る役割をしているのではないかと予想される。 たと壳ば，病的に肺血管抵抗が上昇した場合， 種々の原因による肺高血圧症, primary pulmonary hypertension 等病的状況に招いて chronic に抑制する作用が考光られ，更にはこ の inhibitory nerve system が欠除することが これらの疾患の発病もしくは発症の促進にかか わっている可能性もある。

\section{語}

nerve は共に肺動脈拡張に向らかの作用をして いる可能性はあるが，主な system ではない。

4. ネコ肺動脈に招いては, non adrenergic non cholinergic nerve が inhibitory nerve system の中で主な役割をはたしていることが 示された。

献

Aviado, D.M. (1965). The lung circulation. vol 1, pp 323-354, Pergamon, Oxford.

Bergofsky, E.H. (1979). Active control of the normal pulmonary circulation. In: Pulmonary vascular disease, ed. by K.M. Moser, pp. 233-273, Marcel Dekker Inc., New York.

Bloom, S.R. and Edwards, A.V. (1980). Vasoactive intestinal peptide in relation to atropine resistant vasodilatation in the submaxillary gland of the cat. J. Physiol. $300: 41-51$.

Bulbring, E. and Tomita, T. (1966). Properties of the inhibitory potential of smooth muscle as observed in the response to field stimulation of the guinea pig taenea coli. J. Physiol. 189: 299-315.

Burnstock, G. (1975). Pharmacological review. In: Handbook of psychopharmacology, ed. by L.L. Iversen, et al, pp. 509, Plenum, New York.

Coburn, R.F. and Tomita, T. (1973). Evidence for non adrenergic inhibitory nerves in the guinea pig trachealis muscle. Amer. J. Physiol. 224: 1072-1080.

Daley, R. (1975). The autonomic nervous system in its relation to some forms of heart and lung disease. Br. Med. J. 2 : 173-184.

Hamasaki, Y. Mojarad, M. and Said, S.I. (1983). Relaxant action of VIP on cat pulmonary artery : comparison with acetylcholine, isoproterenol and $\mathrm{PGE}_{1}$. J. Appl. Physiol. 54: 1607-1611.

Hand, J.M., Laravuso, R.B. and Will, J.A. (1983). A non adrenergic relaxant response of isolated guinea pig pulmonary artery to field stimulation. Fed. Proc. 42: 490.

Harns, P. and Heath, D. (1977). The human pulmonary circulation, pp. 37, Churchill Livingstone, Edenbergh, London and New York.

Hugues, J. and Vane, J.R. (1967). An analysis of the responses of the isolated portal vein of the rabbit to electrical stimulation and drugs. Br. J. Pharmac. Chemother. 30:46-66.

Irvin, C.G. et al. (1979). Bronchodilatation: non cholinergic, non adrenergic mediation demonstrat- 
ed in vivo in the cat. Science $207:$ 791-792.

Lundberg, J.M. et al. (1979). Substance-P-, VIP-, and Enkephalin-like immunoreactivity in the human vagus nerve. Gastroenterology 77 : 468-471.

Matsuzaki, Y. Hamasaki, Y. and Said, S.I. (1980). Vasoactive intestinal peptide : A possible transmitter of non adrenergic relaxation of guinea pig airways. Science 210 : 1252-1253.

Paton, W.D. (1955). The response of the guinea pig ileum to electrical stimulation by co-axial electrodes. J. Physiol. 127 : 40-41.

Richardson, J. and Beland, J. (1976). Non adrenergic inhibitory nervous system in human airway. J. Appl. Physiol. 41 : 764-771.

Rucolph, A.M. Duncan, S.R. and Kurland D. (1958). Effects of drugs on normal and on serotoninconstricted pulmonary vessels. Fed. Proc. 17 : 137.

（1984 年 4 月 13 日受付） 